\title{
Comparison of three respiratory physical therapy techniques and their impact on pulmonary function restoration among cardiac surgery patients in hospital settings
}

\section{V. Vitomskyi® *}

${ }^{1}$ National University of Ukraine on Physical Education and Sport, Kyiv, Ukraine, ${ }^{2} \mathrm{Gl}$ "Scientific and Practical Medical Center for Pediatric Cardiology and Cardiac Surgery of the Ministry of Health of Ukraine" (Ukrainian Children's Cardiac Center), Kyiv, Ukraine

The aim. To compare three respiratory physical therapy techniques and their impact on pulmonary function restoration among cardiac surgery patients in hospital settings.

Materials and methods. The study involved 126 patients of both sexes who were admitted for cardiac surgery. All the procedures were performed by sternotomy with cardiopulmonary bypass and cardioplegic arrest.

The patients were randomly divided (with a ratio of 1:1:1 by envelope method) into the control group (CG, $n=42$ ), incentive spirometry group (ISG, $n=42$ ) and inspiratory muscle training group (IMTG, $n=42$ ). The examined patients underwent standardized physical therapy (early mobilization; therapeutic exercises; coughing). The groups varied in respiratory therapy.

Patients of the ISG group performed additional respiratory exercises using a Tri-Ball respiratory exerciser (three repetitions of 10 forced, full and rapid inspirations through the respiratory exerciser under the supervision of a physical therapist; besides, they were recommended to perform 3 repetitions with 10 inspirations each hour). Patients of the IMTG group performed additional respiratory exercises using Respironics Threshold IMT breathing exerciser, received explanations and recommendations like patients of the ISG group.

The pulmonary function test (PFT) was performed for the patients of all groups before the surgery and on the 7 postoperative day.

Results. PFT scores did not differ statistically between the groups of patients before the surgery. The three groups of patients had a negative dynamic of all test indicators, except Tiffeneau index. The analysis of PFT final scores did not confirm a significant difference in the studied indicators among the groups: vital capacity $(P=0.599)$, forced vital capacity $(P=0.393)$, forced expiratory volume in one second $(P=0.589)$, peak expiratory flow $(P=0.326)$, forced inspiratory vital capacity $(P=0.258)$, peak inspiratory flow $(P=0.569)$.

Conclusions. Statistical analysis of PFT indicators did not reveal any significant differences among the groups of cardiac surgery patients at the preoperative examination and on the 7 postoperative day, despite the differences in postoperative respiratory physical therapy.

\section{Порівняння впливу трьох підходів до респіраторної фізичної терапії на відновлення мегеневої функції в кардіохірургічних пацієнтів на стаціонарному етапі}

\section{В. В. Вітомський}

Мета роботи - порівняти вплив трьох підходів до респіраторної фізичної терапії на відновлення легеневої функції в кардіохірургічних пацієнтів на стаціонарному етапі.

Матеріали та методи. У дослідженні взяли участь 126 пацієнтів обох статей, котрим зробили операцію. Всі процедури здійснили зі стернотомією, штучним кровообігом, кардіоплегією.

Пацієнтів випадковим чином поділили (у співвідношенні 1:1:1, метод конвертів) на контрольну групу (КГ, $\mathrm{n}=42$ ), групу стимулювальної спірометрії (ISG, $n=42$ ) та групу інспіраторних м'язових тренувань (IMTG, $n=42$ ). Пацієнтам призначали стандартну програму фізичної терапії (рання мобілізація, терапевтичні вправи, кашель). Групи відрізнялися за респіраторною терапією.

Пацієнти групи ISG виконували додаткові дихальні вправи за допомогою дихального тренажера Tri-Ball (три підходи з 10 сильних, повних і швидких вдихів через дихальний тренажер під наглядом фізичного терапевта; крім того, їм рекомендували виконувати 3 підходи з 10 вдихів кожну годину). Пацієнти групи IMTG виконували додаткові дихальні вправи за допомогою дихального тренажера Respironics Threshold IMT, отримували пояснення та рекомендації як пацієнти групи ISG.

Перед операцією та на 7 післяопераційний день пацієнтам усіх груп виконали спірографрію.

Результати. Результати спірографії статистично не відрізнялись у групах пацієнтів до операції. Усі пацієнти мали негативну динаміку всіх показників, крім індексу Тіфно. Аналіз прикінцевих результатів спірографії не підтвердив вірогідної різниці між групами за показниками, які вивчали: життєвою ємністю ( $p=0,599)$, фрорсованою життєвою ємністю ( $p=0,393)$, об'ємом форсованого видиху за першу секунду ( $p=0,589)$, піковим потоком видиху $(p=0,326)$, життєвою ємністю форсованого вдиху $(p=0,258)$, піковим потоком вдиху $(p=0,569)$.

Висновки. Статистичний аналіз показників спірографії не показав суттєві відмінності груп кардіохірургічних пацієнтів під час передопераційного тестування та на 7 післяопераційний день, незважаючи на відмінності післяопераційної респіраторної фрізичної терапії.
Key words: physical therapy, incentive spirometry, inspiratory muscle training, cardiac rehabilitation.

\section{Zaporozhye} medical journa 2021; 23 (4), 531-535

*E-mail: vitomskiyvova@gmail. com

\section{Ключові слова:} фізична терапія, стимулювальна спірометрія, тренування Аихальних м'язів, кардіореабілітація.

Запорізький медичний журнал. 2021. T. 23, № 4(127). C. 531-535 
Ключевые слова: физическая терапия, стимулирующая спирометрия, тренировки дыхательных мышц, кардиореабилитация.

Запорожский медицинский журнал. 2021. T. 23, № 4(127) C. $531-535$

\section{Сравнение влияния трёх подходов к респираторной физической терапии на восстановление лёгочной функции у кардиохирургических пациентов на стационарном этапе}

\section{В. В. Витомский}

Цель работы - сравнить влияние трёх подходов к респираторной физической терапии на восстановление лёгочной функции у кардиохирургических пациентов на стационарном этапе.

Материалы и методы. В исследовании приняли участие 126 пациентов обоих полов, которым проведена операция. Все процедуры выполняли со стернотомией, искусственным кровообращением и кардиоплегией. Пациентов случайным образом поделили (в соотношении 1:1:1, метод конвертов) на контрольную группу (КГ, $n=42$ ), группу стимулирующей спирометрии (ISG, $n=42$ и и группу инспираторных мышечных тренировок (IMTG, $n=42$ ). Пациентам назначена стандартная программа физической терапии (ранняя мобилизация, терапевтические упражнения, кашель). Группы отличались по респираторной терапии. Пациенты группы ISG выполняли дополнительные дыхательные упражнения с помощью дыхательного тренажёра Tri-Ball (три повторения 10 сильных, полных и быстрых вдохов через дыхательный тренажёр под наблюдением физического терапевта, кроме того, им рекомендовали выполнять 3 повторения по 10 вдохов каждый час). Пациенты группы IMTG выполняли дополнительные дыхательные упражнения с помощью дыхательного тренажёра Respironics Threshold IMT, получали объяснения и рекомендации, как пациенты группы ISG. Перед операцией и на 7 послеоперационный день пациентам всех групп проведена спирография.

Результаты. Результаты спирографии статистически не отличались в группах пациентов до операции. Все пациенты имели отрицательную динамику всех показателей, кроме индекса Тифно. Анализ заключительных результатов спирографии не показал достоверную разницу между группами по исследуемым показателям: жизненной ёмкости $(p=0,599)$, форсированной жизненной ёмкости ( $p=0,393)$, объёму форсированного выдоха за первую секунду $(p=0,589)$, пиковому потоку выдоха ( $p=0,326)$, жизненной ёмкости форсированного вдоха $(p=0,258)$, пиковому потоку вдоха $(p=0,569)$.

Выводы. Статистический анализ показателей спирографии не выявил существенных отличий групп кардиохирургических пациентов при предоперационном тестировании и на 7 послеоперационный день, несмотря на различия послеоперационной респираторной физической терапии.

Physical therapy (PT) in cardiac surgery (CS) and cardiac patients remains an important healthcare sphere due to the prevalence of cardiac pathology, its complications and comorbidity [1,2].

Typical changes in the respiratory system after cardiac surgery involve reduced lung function [3,4], worsening of chest X-ray findings [5], oxygen deficiency in arterial blood for several days [6], reduced respiratory muscle strength [7] and the presence of pleural effusion [8]. On the other hand, a prominent consequence of general anesthesia is decreased pulmonary ventilation [9]. At the same time, scientific studies show that the definition and distinction between normal condition and complications is the reason for high variability of postoperative pulmonary complications (PPCs) among cardiac surgery patients - from $5 \%$ to $90 \%$ [10].

Such interventions of physical therapists as early mobilization and respiratory muscle training are routinely performed to prevent and treat reduced pulmonary function and PPCs [11]. Given the presence of reduced pulmonary function in cardiac surgery patients, it seems relevant to find the ways to improve the process of its restoration.

According to the surveys of physical therapists, there is a wide range of respiratory interventions used in physical therapy for cardiac surgery patients $[12,13]$. The main respiratory PT interventions include coughing, deep breathing exercises, sustained maximal inspiration, pursedlip breathing, diaphragmatic breathing, inspiratory muscle training (IMT), incentive spirometry (IS), positive expiratory pressure device breathing, continuous positive airway pressure, inspiratory resistance - positive expiratory pressure.

On the other hand, when analyzing the examination results, researchers emphasize that physical therapists tend to use interventions with refuted or unconfirmed efficiency $[13,14]$. For instance, scientific studies did not confirm the efficiency of using deep breathing exercise, IS
$[15,16]$, inspiratory resistance-positive expiratory pressure [17]. Concerning the postoperative use of IMT, the studies have proved its benefits manifested in better dynamic of maximum inspiratory pressure and lung function $[18,19]$.

However, flow-oriented IS and IMT techniques are very similar, since they require the patient to take a deep breath in order to perform a certain activity (to lift three balls of a breathing exerciser for flow oriented IS and open the valve of a breathing exerciser for IMT). Therefore, due to the lack of studies focused on IMT efficiency, different methods of examination, similar ways of using breathing exercisers, lack of comparison between IS and IMT techniques, it is advisable to weigh the benefits of using these respiratory interventions to rationalize PT guidelines for treatment of cardiac surgery patients.

\section{Aim}

To compare three respiratory physical therapy techniques and their impact on pulmonary function restoration among cardiac surgery patients in hospital settings.

\section{Materials and methods}

Design: randomized controlled trial.

Participants. The study involved 126 patients of both sexes who were admitted for CS. All the procedures were performed by sternotomy with cardiopulmonary bypass and cardioplegic arrest.

The exclusion criteria were: unstable angina pectoris at the time of study enrollment or during the program, congestive decompensated heart failure, intellectual disability, complex ventricular and uncontrolled arrhythmia, uncontrolled high blood pressure, cerebrovascular accident, artificial lung ventilation $<24$ hours. 
The patients were randomly divided (at a ratio of 1:1:1 by envelope method) into the control group (CG, $n=42)$, IS group (ISG, $n=42$ ) and IMT group (IMTG, $n=42$ ). The study protocol was approved by the Institutional Review Board and the Local Medical Ethics Committee of SI "Scientific and Practical Medical Center for Pediatric Cardiology and Cardiac Surgery of the Ministry of Health of Ukraine" (Protocol No. 1 dated 21.01.2020). All the patients were informed about the study protocol and gave written informed consent.

Interventions. The examined patients underwent standardized PT (early mobilization; therapeutic exercises; coughing). Immediately prior to the surgery, physical therapists provided brief consultations to the patients covering the aims and content of PT and postsurgery activation algorithm. The postoperative PT guidelines supposed performing the following early mobilization activities for patients: sitting on the bed with the legs dangling on the 1 postoperative day (POD); standing (getting up with the help and under the supervision of a physical therapist, holding on a medical movable walker, determined by an anesthesiologist) and walking on the spot if feasible on the 1-2 POD; walking on the spot, walking within the ward on the $2 \mathrm{POD}$; walking in the hospital corridor on the $3 \mathrm{POD}$; walking up and down the stairs on the 4-5 POD. All the patients performing therapeutic exercises and walking were supervised by physical therapists. Sessions (about 20 minutes each) with the physical therapists took place twice a day on the 1 and 2 PODs, $1-2$ times on the 3 POD, 1 time starting from the $4 \mathrm{POD}$. If necessary (patient's condition, the need for motivation), the physical therapist could increase the session frequency and duration. PT was conducted by two physical therapists in equal amount in each group. Each physical therapist was assigned to each group in turn.

The groups varied in respiratory therapy. The ISG group patients performed additional respiratory exercises using a Tri-Ball respiratory exerciser (three repetitions of 10 forced, full and rapid inspirations through the respiratory exerciser at the sessions under the supervision of a physical therapist; besides, they were recommended to perform 3 repetitions with 10 inspirations each hour to lift all three balls of the respiratory exerciser ( $600 \mathrm{cc} / \mathrm{sec}, 900 \mathrm{cc} / \mathrm{sec}$ and $1200 \mathrm{cc} / \mathrm{sec}$ ) with each inhalation. Patient's inability to lift all three balls was not considered a treatment failure, because participant grouping on this basis would contribute to concentration of patients with better scores in ISG. At the same time, such selection would be impossible in CG. ISG patients were asked to start from a lower lung volume before starting the forced inhalation. Training with the use of the respiratory exerciser started from the $1 \mathrm{POD}$. During the 1 and 2 PODs, the exercises were performed each hour and supervised by medical personnel, then the patients recorded performed exercises in self-reported diaries.

The IMTG group patients performed additional respiratory exercises using Respironics Threshold IMT respiratory exerciser (the intensity was measured according to the Rating of Perceived Exertion - hard level; the pressure to open the valve was $18-20 \mathrm{~cm}$ water level starting from the $1 \mathrm{POD}$ and $25-30 \mathrm{~cm}$ water level starting from the 3 $\mathrm{POD}$ ) and received explanations and recommendations like the ISG group patients.

All the participants in ISG and IMTG groups recorded their daily respiratory exercises in the diaries.
Outcome measures. Demographic variables and clinical history were recorded at enrollment to the study. Before the surgery and on the $7 \mathrm{POD}$, the patients of all the groups performed pulmonary function test (PFT) using Spirodoc MIR spirograph and Winspiro PRO software. Normal conditions were assessed according to the Knudson/ European Respiratory Society.

Statistical analysis. The study materials were processed using IBM SPSS 21 program of statistical analysis. Mathematical processing of numerical data was performed with the help of variation statistics. The Shapiro-Wilk test (W) was used to analyze the normality of quantitative indicators distribution. Mean value and root-mean-square deviation $( \pm S)$ were calculated for the results of indicators that corresponded to the law of normal distribution. Median value (Me) and upper and lower quartiles (25 \%; $75 \%$ ) were calculated for non-normally distributed indicators. One-way analysis of variance was used to measure the significance of differences between normally distributed study results; the Kruskal-Wallis test was used for the indicators with non-normal distribution.

\section{Results}

CG included 29 males and 13 females, ISG included 26 males and 16 females, and IMTG included 26 males and 16 females $(P=0.738)$. Significant differences in age, body weight, body length, NYHA functional class, operation duration were not found (Table 1). None of the patients had significant complications aggravating the process of postoperative recovery.

The groups of patients had no statistical differences in PFT scores before CS (Table 2). Six patients of CG had $\mathrm{FEV}_{1} N \mathrm{NC}$ indicators less than $70 \%$, the number of such patients in ISG and IMTG groups comprised 8 and 2, respectively $(P=0.137)$.

Comparison of the pulmonary function test results obtained on the 7 POD did not reveal any statistical difference among groups of patients (Table 3). Therefore, the results of statistical analysis did not confirm the benefits of adding IS or IMT to the basic PT guidelines.

\section{Discussion}

The conducted statistical analysis did not confirm any benefits from including flow oriented IS or IMT to the basic guidelines for the treatment of cardiac surgery patients. Besides, pulmonary function indicators in ISG and IMTG groups were similar, both before and after the surgery. Accordingly, a decrease in the PFT indicators in the patient groups was similar as well. It should be noted that $61.9 \%$ of ISG patients lifted all three balls of the Tri-Ball respiratory exerciser with forced inhalation at the final measuring, $31 \%$ lifted two balls, $7.1 \%$ lifted only one ball. At the time of the final measuring, $61.9 \%$ of IMTG patients used the Respironics Threshold IMT with water column pressure of $30 \mathrm{~cm}$, $9.5 \%$-water column pressure of $25 \mathrm{~cm}, 28.6 \%$-water column pressure of $20 \mathrm{~cm}$.

Volume and flow indicators decreased on the $7 \mathrm{POD}$ in all studied groups of patients. Vital capacity indicator decreased by $27.11 \%$ in CG, by $29.83 \%$ and $26.93 \%$ in ISG and IMTG, respectively. Forced vital capacity dynamic 
Table 1. The main characteristics of the samples

\begin{tabular}{|c|c|c|c|c|}
\hline Indicators & $C G(n=42)$ & ISG (n = 42) & IMTG (n = 42) & $\mathbf{P}$ \\
\hline Age, years & $62(53 ; 68)$ & $64(55.50 ; 70)$ & $64(57 ; 69)$ & $0.525^{*}$ \\
\hline Body weight, $\mathrm{kg}$ & $82.37 \pm 14.91$ & $82.35 \pm 15.25$ & $79.07 \pm 13.48$ & $0.493^{\#}$ \\
\hline Body length, cm & $169.41 \pm 9.19$ & $167.45 \pm 9.55$ & $166.93 \pm 9.27$ & $0.443^{\#}$ \\
\hline Body mass index, $\mathrm{kg} / \mathrm{m}^{2}$ & $28.68 \pm 4.73$ & $29.37 \pm 4.92$ & $28.40 \pm 4.42$ & $0.618^{\#}$ \\
\hline $\mathrm{EF}, \%$ & $55.00(47.75 ; 58.25)$ & $55.0(49.0 ; 58.5)$ & $53(44 ; 58)$ & $0.670^{*}$ \\
\hline $\mathrm{AH}$, degree & $2(0 ; 3)$ & $2(2 ; 3)$ & $2(2 ; 3)$ & $0.420^{*}$ \\
\hline NYHA, class & $2(2 ; 3)$ & $3(2 ; 3)$ & $2.5(2 ; 3)$ & $0.578^{*}$ \\
\hline ALV duration, hour & $7.0(6.0 ; 9.5)$ & $8.5(6.0 ; 12.0)$ & $8.00(6.00 ; 9.75)$ & $0.208^{*}$ \\
\hline Operation duration, min & $377.5(330.0 ; 422.5)$ & $342.50(295.00 ; 416.25)$ & $370(320 ; 445)$ & $0.330^{*}$ \\
\hline CPB duration, min & $179.33 \pm 56.57$ & $186.19 \pm 56.43$ & $198.29 \pm 67.81$ & $0.351^{\#}$ \\
\hline LICU, nights & $2(2 ; 2)$ & $2(2 ; 2)$ & $2(2 ; 2)$ & $0.444^{*}$ \\
\hline LPOU, nights & $7(5 ; 8)$ & $7(5.75 ; 9.25)$ & $7.00(6.00 ; 9.25)$ & $0.456^{*}$ \\
\hline
\end{tabular}

EF: ejection fraction; AH: arterial hypertension; ALV: artificial lung ventilation; CPB: cardiopulmonary bypass; LICU: length of intensive care unit stay; LPOU: length of postoperative unit stay; \#: one-way analysis of variance; *: Kruskal-Wallis test.

Table 2. The pulmonary function test indicators before the surgery

\begin{tabular}{|c|c|c|c|c|}
\hline Indicators & $C G(n=42)$ & ISG ( $n=42)$ & IMTG (n = 42) & $\mathbf{P}^{*}$ \\
\hline VC, \% predicted & $102.02 \pm 15.55$ & $104.93 \pm 14.03$ & $104.95 \pm 19.95$ & 0.653 \\
\hline FVC, \% predicted & $100.60 \pm 14.57$ & $101.24 \pm 14.43$ & $104.10 \pm 19.86$ & 0.586 \\
\hline $\mathrm{FEV}_{1}, \%$ predicted & $99.55 \pm 18.84$ & $101.10 \pm 14.98$ & $104.31 \pm 19.96$ & 0.470 \\
\hline $\mathrm{FEV}_{1} / \mathrm{VC}, \%$ & $77.94 \pm 9.80$ & $76.35 \pm 8.39$ & $79.95 \pm 7.36$ & 0.161 \\
\hline PEF, \% predicted & $96.41 \pm 15.42$ & $100.43 \pm 19.75$ & $101.29 \pm 17.89$ & 0.408 \\
\hline $\mathrm{FEF}_{25-75}, \%$ predicted & $87.79 \pm 29.51$ & $94.79 \pm 33.10$ & $91.17 \pm 28.95$ & 0.578 \\
\hline FIVC, \% predicted & $96.10 \pm 15.05$ & $95.55 \pm 16.36$ & $101.17 \pm 20.11$ & 0.264 \\
\hline $\mathrm{FIV}_{1}, \%$ predicted & $114.19 \pm 21.14$ & $115.17 \pm 20.79$ & $121.31 \pm 24.88$ & 0.289 \\
\hline PIF, \% predicted & $70.43 \pm 18.65$ & $70.17 \pm 22.10$ & $71.17 \pm 17.01$ & 0.970 \\
\hline
\end{tabular}

VC: vital capacity; FVC: forced vital capacity; FEV1: forced expiratory volume in one second; FEV1/VC: Tiffeneau index; PEF: peak expiratory flow; FEF25-75: forced expiratory flow at $25-75 \%$ of forced vital capacity; FIVC: forced inspiratory vital capacity; FIV1: forced inspiratory volume in one second; PIF: peak inspiratory flow; *: one-way analysis of variance.

Table 3. The pulmonary function test indicators on the seventh postoperative day

\begin{tabular}{|c|c|c|c|c|}
\hline Indicators & $C G(n=42)$ & ISG $(n=42)$ & IMTG $(n=42)$ & $\mathbf{P}^{*}$ \\
\hline VC, \% predicted & $74.91 \pm 14.93$ & $75.10 \pm 17.37$ & $78.02 \pm 14.99$ & 0.599 \\
\hline FVC, $\%$ predicted & $74.07 \pm 15.02$ & $73.26 \pm 18.33$ & $77.81 \pm 15.03$ & 0.393 \\
\hline $\mathrm{FEV}_{1}, \%$ predicted & $74.55 \pm 15.41$ & $75.17 \pm 18.83$ & $78.10 \pm 16.05$ & 0.589 \\
\hline $\mathrm{FEV}_{1} / \mathrm{VC}, \%$ & $79.78 \pm 8.53$ & $79.11 \pm 8.48$ & $79.78 \pm 9.35$ & 0.923 \\
\hline PEF, \% predicted & $78.64 \pm 18.42$ & $82.57 \pm 23.44$ & $85.52 \pm 20.91$ & 0.326 \\
\hline $\mathrm{FEF}_{25-75}, \%$ predicted & $68.43 \pm 23.72$ & $74.12 \pm 31.30$ & $68.07 \pm 24.84$ & 0.513 \\
\hline FIVC, \% predicted & $70.62 \pm 15.28$ & $69.43 \pm 18.68$ & $75.10 \pm 15.48$ & 0.258 \\
\hline FIV $_{1}, \%$ predicted & $86.10 \pm 19.14$ & $84.74 \pm 23.62$ & $89.00 \pm 19.25$ & 0.632 \\
\hline PIF, \% predicted & $58.48 \pm 15.50$ & $58.12 \pm 18.69$ & $61.74 \pm 17.18$ & 0.569 \\
\hline
\end{tabular}

VC: vital capacity; FVC: forced vital capacity; FEV1: forced expiratory volume in one second; FEV1/VC: Tiffeneau index; PEF: peak expiratory flow; FEF25-75: forced expiratory flow at 25-75\% of forced vital capacity; FIVC: forced inspiratory vital capacity; FIV1: forced inspiratory volume in one second; PIF: peak inspiratory flow; *: one-way analysis of variance.

comprised $26.53 \%, 27.98 \%$ and $26.29 \%$, respectively. Peak expiratory flow indicator had a less pronounced dynamics as compared to the mentioned volume indicators, namely a $17.77 \%$ decrease was obtained in CG, $17.86 \%$ - in ISG; $15.77 \%$ - in IMTG. The mean value of peak inspiratory flow had even less decrease: $11.95 \%$ in CG; $12.05 \%$ in ISG; $9.4 \%$ in IMTG. Only FEV 1 NC indicators did not have negative changes confirming the absence of obstructive pulmonary dysfunction caused by cardiac surgery. Therefore, the negative dynamics was more pronounced among the indicators of PFT volumes in comparison to flow indicators. It is noteworthy that the indicators of forced inhalation did not vary among the groups, although both respiratory exercisers were aimed at training forced, full and rapid inhalation.

The study not only confirmed previously obtained results stating the lack of IS efficiency $[15,16]$, but supplemented existing data on the efficiency of using IMT.
Preceding studies of IMT efficiency confirmed its positive effect, particularly (after transfer to the inpatient unit until hospital discharge) on the dynamics of MIP indicator (maximum inspiratory pressure) [20]. Another study confirmed positive impact of IMT, starting on the $1 \mathrm{POD}$, on vital capacity and tidal volume indicators, measured on the 3 POD [21]. However, there was nothing about benefits in MIP and MEP (maximum expiratory pressure) in the study, although these indicators were examined. Besides, vital capacity was measured quite early and in $\mathrm{ml}$, which could affect the statistical analysis results.

According to another study, the use of IMT in pre- and postoperative periods did not result in better dynamics of $\mathrm{FEV}_{1}, \mathrm{FVC}$ and MEP indicators, leading not only to recovery but also to MIP increase at the time of discharge (the 5-6 day) [19]. However, according to other studies, MIP may not return to its original indicators even 8 weeks postsurgery [22]. Such differences in the recovery process cast doubt on the validity of the results. 
The study of C. Urell et al. [10] states that respiratory muscle strength is restored two months after CS, unlike PFT indicators. Therefore, in order to improve PFT indicators, it is better not to focus on training respiratory muscle strength immediately following the surgery.

\section{Conclusions}

1. Statistical analysis of PFT indicators did not reveal any significant differences among the groups of cardiac surgery patients at the preoperative examination and on the 7 postoperative day, despite the differences in postoperative respiratory physical therapy. Thus, flow-oriented IS or IMT included in the basic postoperative physical therapy guidelines, where the respiratory part was limited to coughing, did not contribute to pulmonary function restoration.

2. All three groups had a significant decrease in volume and flow indicators. The obtained negative dynamics of flow indicators was less pronounced. Forced inhalation indicators were also similar in all the groups, although respiratory exercisers were aimed at respiratory training. IS or IMT should not be used in physical therapy to improve pulmonary function in the inpatient phase of rehabilitation after cardiac surgery.

Conflicts of interest: author has no conflict of interest to declare. Конфлікт інтересів: віАсутній.

Надійшла Ао редакції / Received: 10.03.2021

Після Аоопрацювання / Revised: 26.03.2021

Прийнято Ао Аруку / Accepted: 07.04.2021

Information about author:

Vitomskyi V. V., PhD, Lecturer of the Department of Physical Therapy and Ergotherapy, National University of Ukraine on Physical Education and Sport; physical therapist, SI "Scientific and Practical Medical Center for Pediatric Cardiology and Cardiac Surgery of the Ministry of Health of Ukraine" (Ukrainian Children's Cardiac Center), Kyiv.

ORCID ID: 0000-0002-4582-6004

\section{Відомості про автора:}

Вітомський В. В., канА. наук з фізичного виховання та спорту, викладач каф. фізичної терапії та ерготерапії, Національний університет фізичного виховання і спорту України; фахівець із фізичної реабімітації, АУ «Науково-практичний меАичний центр Аитячої кардіології та кардіохірургії М0З України", м. Київ.

\section{Сведения об авторе:}

Витомский В. В., канА. наук по физическому воспитанию и спорту, преподаватель каф. физической терапии и эрготерапии, Национальный университет физического воспитания и спорта Украины; специалист по физической реабилитации, ГУ „Научнопрактический меАицинский центр Аетской карАиологии и кардиохирургии МЗ Украины", г. Киев.

\section{References}

[1] Balazh, M., Kormiltsev, V., Kostenko, V., Vitomskyi, V., Strohanov, S., Sabadosh, M., Yurchenko, O., \& Martseniuk, I. (2020). Physical rehabilitation program of patients with ischemic heart disease with metabolic syndrome. Journal of Physical Education and Sport, 20(6), 3528-3535. https://doi.org/10.7752/jpes.2020.06476

[2] Vitomskiy, V., Hruzevych, I., Salnykova, S., Sulyma, A., Kormiltsev, V., Kyrychenko, Y., \& Sarafinjuk, L. (2018). The physical development of children who have a functionally single heart ventricle as a basis for working physical rehabilitation technology after a hemodynamic correction. Journal of Physical Education and Sport, 18(2), 614-617. https://doi. org/10.7752/jpes.2018.02089
[3] Guizilini, S., Gomes, W. J., Faresin, S. M., Carvalho, A. C. C., Jaramillo, J. I., Alves, F. A., Catani, R., \& Buffolo, E. (2004). Efeitos do local de inserção do dreno pleural na função pulmonar no pós-operatório de cirurgia de revascularização do miocárdio. Revista Brasileira de Cirurgia Cardiovascular, 19(1), 47-54. https://doi.org/10.1590/s0102-76382004000100010

[4] Vitomskyi, V., Al-Hawamdeh, K., Vitomska, M., Lazarieva, O., \& Haidai, O. (2021). The effect of incentive spirometry on pulmonary function recovery and satisfaction with physical therapy of cardiac surgery patients. Advances in Rehabilitation, 35(1), 9-16. https://doi.org/10.5114/areh.2020.102020

[5] Oikkonen, M., Karjalainen, K., Kähärä, V., Kuosa, R., \& Schavikin, L. (1991). Comparison of Incentive Spirometry and Intermittent Positive Pressure Breathing after Coronary Artery Bypass Graft. Chest 99(1), 60-65. https://doi.org/10.1378/chest.99.1.60

[6] Barbosa, R. A., \& Carmona, M. J. (2002). Avaliação da função pulmonar em pacientes submetidos à cirurgia cardíaca com circulação extracorpórea. Revista brasileira de anestesiologia, 52(6), 689-699. https:// doi.org/10.1590/s0034-70942002000600005

[7] Elias, D. G., Costa, D., Oishi, J., Pires, V. A., \& Silva, M. A. M. (2000) Efeitos do treinamento muscular respiratorio no pre e pos-operatorio de cirurgia cardiaca. Revista Brasileira de Terapia Intensiva, 12(1), 9-18. https://pesquisa.bvsalud.org/portal/resource/pt/lil-283770

[8] Vitomskyi, V. (2020). The impact of mobilization and other factors on pleural effusion in patients undergoing cardiac surgical procedures. Journal of Physical Education and Sport, 20(Suppl. 3), 2167-2173. https://doi. org/10.7752/jpes.2020.s3291

[9] Taşkin, H., Telli Atalay, O., Yuncu, G., Taşpinar, B., Yalman, A., \& Şenol, H. (2020). Postoperative respiratory muscle training in addition to chest physiotherapy after pulmonary resection: A randomized controlled study. Physiotherapy Theory and Practice, 36(3), 378-385. https://doi.or $\mathrm{g} / 10.1080 / 09593985.2018 .1488189$

[10] Urell, C., Emtner, M., Hedenstrom, H., \& Westerdahl, E. (2016). Respiratory muscle strength is not decreased in patients undergoing cardiac surgery. Journal of Cardiothoracic Surgery, 11(1), Article 41. https://doi. org/10.1186/s13019-016-0433-z

[11] Stein, R., Maia, C. P., Silveira, A. D., Chiappa, G. R., Myers, J., \& Ribeiro, J. P. (2009). Inspiratory Muscle Strength as a Determinant of Functional Capacity Early After Coronary Artery Bypass Graft Surgery. Archives of Physical Medicine and Rehabilitation, 90(10), 1685-1691. https://doi.org/10.1016/j.apmr.2009.05.010

[12] Westerdahl, E., \& Möller, M. (2010). Physiotherapy-supervised mobilization and exercise following cardiac surgery: a national questionnaire survey in Sweden. Journal of Cardiothoracic Surgery, 5(1), Article 67. https://doi.org/10.1186/1749-8090-5-67

[13] Lomi, C., \& Westerdahl, E. (2013). Physical Therapy Treatment after Cardiac Surgery: ANational Survey of Practice in Greece. Journal of Clinical \& Experimental Cardiology, S7, Article 004. https://doi.org/10.4172/2155-9880.S7-004

[14] Westerdahl, E., \& Olsén, M. F. (2011). Chest physiotherapy and breathing exercises for cardiac surgery patients in Sweden - A National survey of practice. Monaldi archives for chest disease, 75(2), 112-119. https://doi. org/10.4081/monaldi.2011.223

[15] Dull, J. L., \& Dull, W. L. (1983). Are Maximal Inspiratory Breathing Exercises or Incentive Spirometry Better Than Early Mobilization After Cardiopulmonary Bypass? Physical Therapy, 63(5), 655-659. https://doi. org/10.1093/pt/ $/ 63.5 .655$

[16] Jenkins, S. C., Soutar, S. A., Loukota, J. M., Johnson, L. C., \& Moxham, J. (1990). A comparison of breathing exercises, incentive spirometry and mobilisation after coronary artery surgery. Physiotherapy Theory and Practice, 6(3), 117-126. https://doi.org/10.3109/09593989009037789

[17] Westerdahl, E., Lindmark, B., Almgren, S. O., \& Tenling, A. (2001). Chest physiotherapy after coronary artery bypass graft surgery - a comparison of three different deep breathing techniques. Journal of Rehabilitation Medicine, 33(2), 79-84. https://doi.org/10.1080/165019701750098920

[18] Cargnin, C., Karsten, M., Guaragna, J., \& Dal Lago, P. (2019). Inspiratory Muscle Training After Heart Valve Replacement Surgery Improves Inspiratory Muscle Strength, Lung Function, and Functional Capacity: ARANDOMIZED CONTROLLED TRIAL. Journal of Cardiopulmonary Rehabilitation and Prevention, 39(5), E1-E7. https://doi.org/10.1097/HCR.00000000000000409

[19] Savci, S., Degirmenci, B., Saglam, M., Arikan, H., Inal-Ince, D., Turan, H. N., \& Demircin, M. (2011). Short-term effects of inspiratory muscle training in coronary artery bypass graft surgery: A randomized controlled trial. Scandinavian Cardiovascular Journal, 45(5), 286-293. https://doi.or $\mathrm{g} / 10.3109 / 14017431.2011 .595820$

[20] Cordeiro, A. L., de Melo, T. A., Neves, D., Luna, J., Esquivel, M. S. Guimarães, A. R., Borges, D. L., \& Petto, J. (2016). Inspiratory Muscle Training and Functional Capacity in Patients Undergoing Cardiac Surgery. Brazilian Journal of Cardiovascular Surgery, 31(2), 140-144. https://doi. org/10.5935/1678-9741.20160035

[21] Matheus, G. B., Dragosavac, D., Trevisan, P., Costa, C. E., Lopes, M. M., \& Ribeiro, G. C. (2012). Inspiratory muscle training improves tidal volume and vital capacity after CABG surgery. Revista Brasileira de Cirurgia Cardiovascular, 27(3), 362-369. https://doi.org/10.5935/1678-9741.20120063

[22] Johnson D., Hurst, T., Thomson, D., Mycyk, T., Burbridge, B., To, T., \& Mayers, I. (1996). Respiratory function after cardiac surgery. Journal of Cardiothoracic and Vascular Anesthesia, 10(5), 571-577. https://doi. org/10.1016/s1053-0770(96)80130-3 